O. Koval'chuk, R. Berezhnyj, V. Nezhebovs'kyj, O. Ustynenko, Kharkiv, Ukraine

\title{
ANALYSIS OF TENSENESS AND DURABILITY OF THE MAIN PARTS FOR THE CUTTING PART OF UKD 200-500 COAL SHEARER
}

\begin{abstract}
JSC "Kharkiv Machine-Building Plant "Svitlo Shahtarja" has created and introduced into serial production a new generation UKD200-500 coal shearer. The most loaded element of the shearer is its cutting part. It is a three-stage reducer with an electric motor. Calculations for the strength and durability of gearing, shafts, bearings, spline, pinned and hinge joints have been carried out. The modeling of the stress-strain state for the main parts and assemblies by the finite element method has also been carried out. Calculations have shown that the strength and durability of all parts is ensured. Consequently, the required durability of 15000 hours and the average resource before major overhaul are not less than $800 . . .1000$ thousand tons are provided.
\end{abstract}

Keywords: coal shearer; cutting part; gear; strength; durability; stress.

\section{INTRODUCTION}

The current state of the Ukrainian fuel and energy complex requires a continuous increase in coal production. Currently, $80 \%$ of coal deposits are in thin seams.

As part of the implementation of the concept of development of the coal industry, approved by the order of the Cabinet of Ministers of Ukraine No. 236-r dated July 7, 2005 [1], in order to extract coal from thin seams, JSC "Kharkiv Machine-Building Plant "Svitlo Shahtarja" created and introduced into serial production a new generation UKD200-500 coal shearer. It is designed for mechanized coal extraction as part of mining complexes, in longwalls of shallow and inclined seams $0,85-1,5 \mathrm{~m}$ thickness, moving along strike with inclination angles up to $35^{\circ}$, as well as rise and fall with angles up to $10^{\circ}$, with coal cutting resistance up to $480 \mathrm{kN} / \mathrm{m}$. Its technical characteristics are at the level of modern foreign counterparts.

UKD200-500 coal shearer is a cutting action machine equipped with auger executive bodies for destruction and loading of coal onto a conveyor - Figure 1 Moving the shearer with a scraper conveyor is carried out by means of an external feed system.

The most important and loaded element of the shearer is its cutting part Figure 2, 3. It is a three-stage spur reducer with an electric motor:

- 1st stage is three in-line cylindrical gears, module $m=6 \mathrm{~mm}$;

-2nd stage is planetary single-stage with fixed epicycle, module $m=6 \mathrm{~mm}$;

-3rd stage is four in-line cylindrical gears, module $m=16 \mathrm{~mm}$. 
- Darnel K4-16-233 electric motor, rated power $250 \mathrm{~kW}$, rated speed $1470 \mathrm{rpm}$, asynchronous three-phase with squirrel-cage rotor.

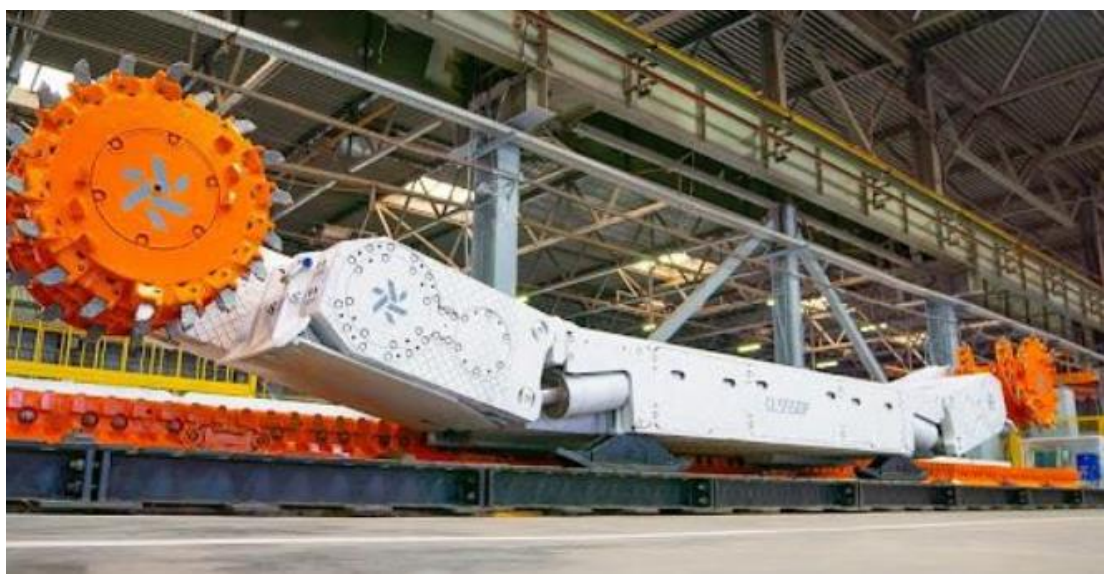

Figure 1 - The UKD200-500 coal shearer

The cutting part of the UKD200-500 coal shearer is unified. This allows it to be installed on either the left or right side of the frame. Each reducer stage is located in a separate sealed chamber, protected from the penetration of abrasive particles.

The material of external gears is Steel 20Ch2N4ASh, with heat treatment carburizing followed by quenching and low tempering. Material of the planetary stage epicycle - Steel $40 \mathrm{ChN}$, with heat treatment - improvement for hardness 270-300HB.
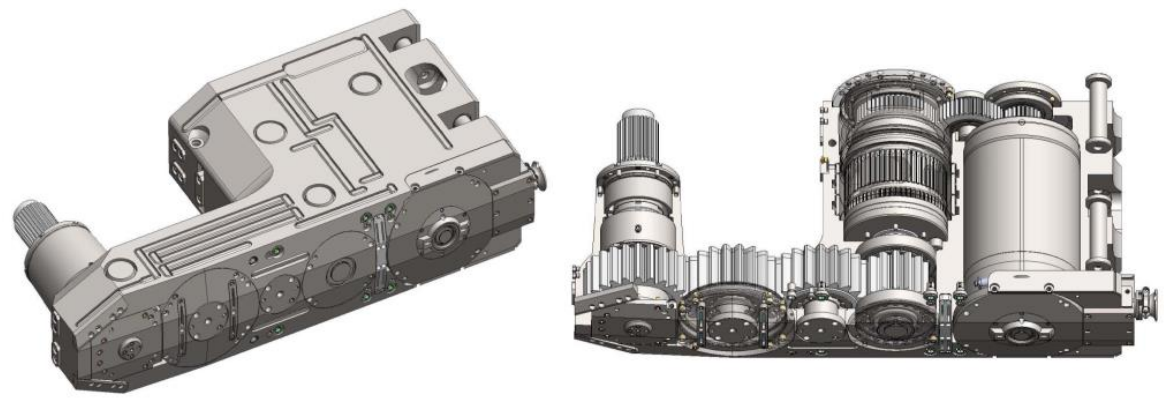

Figure 2 - The cutting part of UKD200-500 coal shearer 


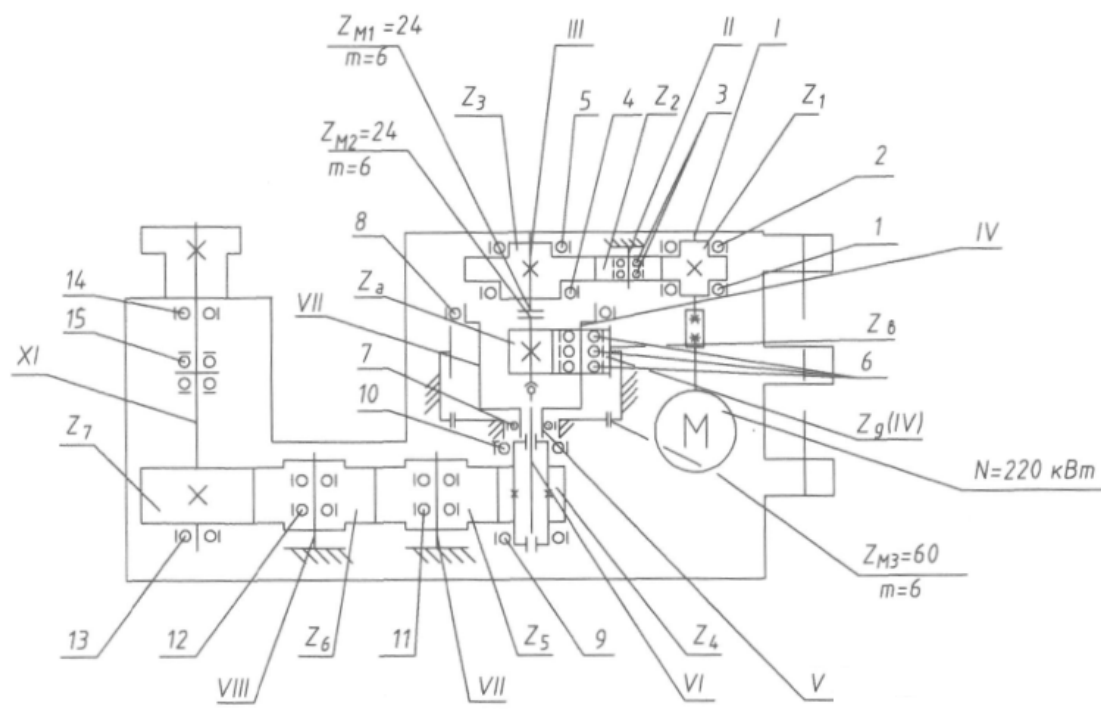

Figure 3 - Kinematic diagram of the cutting part reducer

\section{PROBLEM STATEMENT}

Reliability and durability of the shearer as a whole depend on the reliability and durability of the cutting part, mainly its gears. It is necessary to take into account that coal mining equipment operates in especially difficult conditions. These are elevated temperatures, a wide range of shock loads and extremely high dust levels. In this case, it is required to ensure the high durability of gears and bearings - at least 15000 hours. Based on this, during the design process, as well as in the future, taking into account the operating experience, a large amount of calculations of its main parts for strength and durability was performed, namely:

- calculations for contact and bending fatigue and static strength of gearings;

- calculations of shafts for static and fatigue strength;

- calculation of service life and static strength of bearings;

- calculations of spline, pinned and hinge joints;

- modeling of the stress-strain state for the main parts and assemblies by the finite element method.

Next we will consider the methods, approaches and results of the performed calculations. For gears, as the main and most critical drive element, they will be presented in more detail. For the rest of the calculations, due to the limited volume of the article, we will present only the main results. 


\section{MATERIALS AND METHODS}

Let's start with the basic initial data.

The design load was taken as follows:

- rated torque $T_{r}=1624 \mathrm{~N} \cdot \mathrm{m}$;

- the maximum long-term operating torque for calculating the durability $T_{r M}=3090 \mathrm{~N} \cdot \mathrm{m}[2]$;

- the maximum short-term torque for calculating the static strength $T_{M}=5740 \mathrm{~N} \cdot \mathrm{m}[3]$.

The total estimated resource of the combine is 15000 hours. We assume that each of the two cutting parts works for half of the calculated resource with nominal loads. Therefore, the estimated life for the cutting part is 7500 hours.

The calculation of the gearing geometry, contact and bending stresses in them was carried out on the basis of standard techniques [4-7]. Also, the permissible stresses were refined on the basis of mathematical modeling for fatigue processes in the teeth [8].

The assessment of durability was carried out using the recommendations of GOST 21354-87 [6]: the slight slope of the right branch of the contact fatigue curve was taken into account at the total numbers of stress change cycles $N_{K}>N_{H \text { lim. }}$. Here $N_{H \text { lim }}$ is the base numbers of cycles corresponding to the contact fatigue limit $\sigma_{H \lim b}-$ Figure 4 .

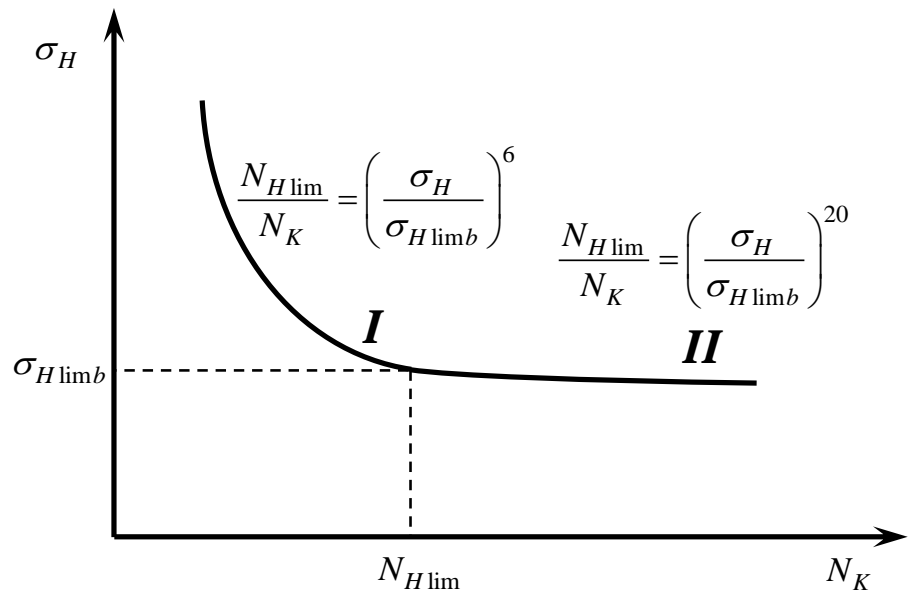

Figure 4 - Contact fatigue curve of active tooth surfaces: $I$ - zone of limited fatigue; $I I$ - zone of long-term fatigue 
The resource calculation was carried out in the next sequence.

1. The equivalent numbers of stress change cycles were determined for calculating the contact and bending fatigue $N_{H E}$ and $N_{F E}$ according to the next formulas [6]:

$$
N_{H E}=\sum_{i=1}^{i_{n}}\left(\frac{T_{1 i}}{T_{1 H}}\right)^{3} N_{c i} ; \quad N_{F E}=\sum_{i=1}^{i_{n}}\left(\frac{T_{1 i}}{T_{1 F}}\right)^{q_{F}} N_{c i} \leq N_{F \lim },
$$

where $i=1 ; \ldots ; i_{n}$ - accepted for calculation load steps in the cyclorama; $T_{1 i}$ and $N_{c i}=60 n_{i} \cdot t_{i}-$ corresponding values of torque and stress cycles on the pinion; $N_{F l i m}$ - base number of cycles corresponding to the bending fatigue $\operatorname{limit} \sigma_{F \lim b}^{0} ; q_{F}=9$ for the case of surface chemo-heat treatment of teeth and an unpolished tooth root; $q_{F}=6$ for other variants of heat treatment or polished tooth root.

Additionally, for case $N_{K}>N_{H \text { lim }}$, steps with loads that create stresses below the so-called damaging level $\sigma_{H G}=\alpha_{H G} \sigma_{H \lim b}$ were excluded from the cyclorama. GOST 21354-87 recommends $\alpha_{H G}=0,75$ [6].

2 . The total number of cycles to failure was calculated.

2.1. Bending fatigue:

$$
\left.\begin{array}{ll}
N_{F \Sigma 1(2)}=\left(\frac{\sigma_{F P 1(2)}}{\sigma_{F 1(2)}}\right)^{q_{F}} N_{F E 1(2)} & \text { if } N_{F \Sigma 1(2)} \leq N_{F \lim 1(2)} ; \\
N_{F \Sigma 1(2)}=\infty & \text { if } N_{F \Sigma 1(2)}>N_{F \lim 1(2)}
\end{array}\right\}
$$

2.2. Contact fatigue:

$$
\left.\begin{array}{l}
N_{H \Sigma}=N_{H E}\left(\frac{\sigma_{H P}}{\sigma_{H}}\right)^{6} \text { if } N_{H E} \leq N_{H \lim } \\
N_{H \Sigma}=N_{H E}\left(\frac{\sigma_{H P}}{\sigma_{H}}\right)^{20} \text { if } N_{H E}>N_{H \lim } \cdot
\end{array}\right\}
$$

3. The calculated durability of the teeth was determined by contact and bending fatigue in hours, $L_{H h}$ and $L_{F h}$ :

$$
L_{H h}=t \frac{N_{H \Sigma}}{N_{H E}} ; \quad L_{F h}=\min \left\{t \frac{N_{F \Sigma 1}}{N_{F E 1}}, t \frac{N_{F \Sigma 2}}{N_{F E 2}}\right\},
$$

where $t$ - required resource of gears.

The minimum of $L_{H h}$ and $L_{F h}$ was taken as the final value of the durability $L_{h}$ for each gear pair.

Calculations of shafts, bearings, spline, pinned and hinge joints were carried out on the basis of generally accepted engineering techniques, for example [9]. 
Modeling of the stress-strain state for the main parts and assemblies by the finite element method was carried out in specialized software ANSYS [10] and Autodesk Inventor Nastran (Nastran In-CAD) [11]. The carrier of the planetary stage, reducer housing, shafts, spline parts, etc. were research.

\section{RESULTS AND DISCUSSION}

Calculation results of strength and durability for gearings of the cutting part reducer are presented in Table 1.

Analysis of the data in Table 1 shows that the strength and durability for all gears of the cutting part are ensured.

Table 1 - Calculation results of gears strength and durability

\begin{tabular}{|c|c|c|c|c|c|c|c|c|c|c|}
\hline Gear & \multicolumn{3}{|c|}{ 1st stage } & \multicolumn{3}{|c|}{ 2nd (planetary) stage } & \multicolumn{4}{|c|}{ 3rd stage } \\
\hline $\begin{array}{l}\text { Number of } \\
\text { teeth }\end{array}$ & $Z_{1}$ & $Z_{2}$ & $Z_{3}$ & $Z_{a}$ & $Z_{g}$ & $Z_{b}$ & $Z_{4}$ & $Z_{5}$ & $Z_{6}$ & $Z_{7}$ \\
\hline Module $m, \mathrm{~mm}$ & \multicolumn{3}{|c|}{6} & \multicolumn{3}{|c|}{6} & \multicolumn{4}{|c|}{16} \\
\hline $\begin{array}{l}\text { Contact fatigue } \\
\text { safety factor } S_{H} \\
\left(\left[S_{H}\right]=1,2\right)\end{array}$ & 1,45 & 1,74 & 1,90 & 1,24 & 1,72 & $\begin{array}{c}1,42 \\
{\left[S_{H}\right]=1,1}\end{array}$ & 1,66 & 1,98 & 2,19 & 2,01 \\
\hline $\begin{array}{l}\text { Bending } \\
\text { fatigue safety } \\
\text { factor } S_{F} \\
\left(\left[S_{F}\right]=1,55\right)\end{array}$ & 2,72 & 2,12 & 2,97 & 2.83 & 2,45 & $\begin{array}{c}3,19 \\
{\left[S_{F}\right]=1,7}\end{array}$ & 2,92 & 2,78 & 2,78 & 3,05 \\
\hline $\begin{array}{l}\text { Contact static } \\
\text { strength safety } \\
\text { factor } S_{H M} \\
\left(\left[S_{H M}\right]=1\right)\end{array}$ & 1,93 & 1,93 & 2,32 & $\overline{1,71}$ & 1,71 & 1,69 & 1,50 & 1,50 & 1,65 & 1,65 \\
\hline $\begin{array}{l}\text { Bending static } \\
\text { strength safety } \\
\text { factor } S_{F M} \\
\left(\left[S_{F M}\right]=1,75\right)\end{array}$ & 3,62 & 3,50 & 3,59 & 3,79 & 3,69 & 4,74 & 2,89 & 3,52 & 3,87 & 2,77 \\
\hline $\begin{array}{l}\text { Calculated } \\
\text { service life of } \\
\text { teeth } t \text {, hours }\end{array}$ & 330200 & $12,7 \cdot 10^{6}$ & $73,5 \cdot 10^{6}$ & 14400 & 810500 & $1,2 \cdot 10^{6}$ & 52500 & 151300 & 277100 & 165600 \\
\hline
\end{tabular}

Next are some of the main calculation results for shafts, bearings and joints.

For shafts:

- the calculated safety factors of fatigue strength are in the range $n=1,55 \ldots 15,47$ with the minimum allowable value $[n]=1,5$;

- the calculated safety factors of static strength are in the range $n_{M}=1,55 \ldots 20,33$ with the minimum allowable value of yield strength $\left[n_{M}\right]=1,5$ 
For bearings:

- the calculated service life in terms of dynamic load capacity is in the range $L_{h}=8000 \ldots 4 \cdot 10^{7} \mathrm{~h}$ with the required service life $\left[L_{h}\right]=75000 \mathrm{~h}$;

- the calculated safety factors in terms of static load capacity are in the range $n_{0}=1,5 \ldots 26,0$ with the minimum allowable value $\left[n_{0}\right]=1,0$;

For joints:

- in spline joints, the calculated safety factors of contact stress are in the range $n_{\sigma}=2,68 \ldots 6,17$ with the minimum allowable value $\left[n_{\sigma}\right]=1,0$;

- in pinned joints, the calculated safety factors of contact and shear stress are in the range $n_{\sigma(\tau)}=1,68 \ldots 7,97$ with the minimum allowable value $\left[n_{\sigma(\tau)}\right]=1,0$;

- for the axes of the hinge joints, the calculated safety factors of static strength are in the range $n_{M}=1,21 \ldots 2,8$ with the minimum allowable value $\left[n_{M}\right]=1,2$.

Analysis of these results shows that the strength and durability for the main elements of the cutting part are ensured.

In conclusion, we will give an example of modeling the stress-strain state for main parts and assemblies using the finite element method. Figure 5 shows the distribution of equivalent von Mises stress, MPa, in auger splined bushing.
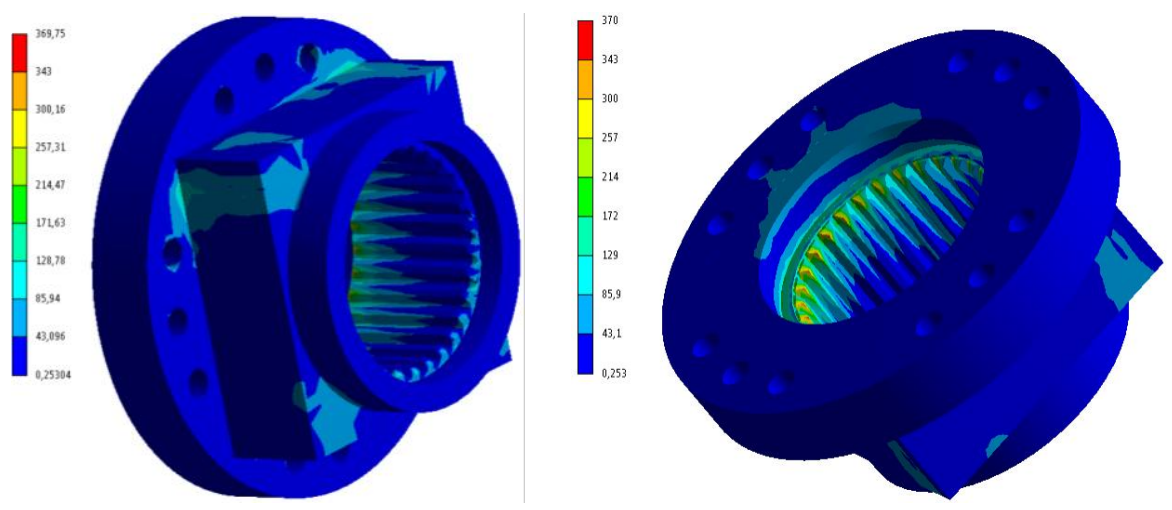

Figure 5 - Equivalent stress by von Mises, MPa, in auger splined bushing

The highest stresses occur in the concentration zone at the edges of the spline teeth. However, in the contact zone of the bushing with the auger, the stress is less than $100 \mathrm{MPa}$. This satisfies the strength conditions. 


\section{SUMMARY}

A detailed assessment of the tenseness and durability of the main parts and assemblies for the cutting part of the UKD200-500 new generation shearer has been carried out. It was created and introduced into serial production at the JSC "Kharkiv Machine-Building Plant "Svitlo Shahtarja". In terms of technical characteristics, the shearer corresponds to modern foreign counterparts.

Calculations and modeling of the stress-strain state showed:

- the strength and durability of all gears and shafts are ensured;

- the calculated service life in terms of dynamic load capacity for all bearings are ensured. Safety factors in terms of static load capacity exceed the minimum allowable values;

- the calculated safety factors of strength for spline, pinned and hinge joints exceed the minimum allowable values;

- modeling of the stress-strain state by the finite element method made it possible to evaluate the strength of parts and assemblies of complex configuration. Calculations have shown that, in terms of the level of maximum stresses, all parts correspond the strength conditions.

Thus, it can be concluded that the developed cutting part design of the UKD200-500 coal shearer provides the required durability of 15000 hours and the average resource before overhaul (depending on the resistance of the coal to cutting) not less than $800 \ldots 1000$ thousand tons.

References: 1. Koncepcija rozvytku vugil'noi' promyslovosti. Shvaleno rozporjadzhennjam Kabinetu Ministriv Ukrai'ny vid 7 lypnja 2005 r. No 236-r [The concept of development of the coal industry. Approved by the order of the Cabinet of Ministers of Ukraine of July 7, 2005 No 236-r]. Available at: https://www.kmu.gov.ua/npas/18609693 (accessed 19 December 2021). 2. KD 12.10.042-99. Izdelija ugol'nogo mashinostroenija. Kombajny ochistnye. Metodika vybora spektrov jekspluatacionnoj nagruzhennosti transmissij [KD 12.10.041-99. Coal engineering products. Coal shearers. Methodology of the spectrum selection for operational loading of transmissions]. Kyiv, 1999. 3. KD 12.10.042-99. Izdelija ugol'nogo mashinostroenija. Kombajny ochistnye. Metodika rascheta maksimal'nyh nagruzok v transmissijah [KD 12.10.042-99. Coal engineering products. Coal shearers. Methodology for calculating the maximum loads in transmissions.]. Kyiv, 1999. 4. GOST 16532-70. Peredachi zubchatye cilindricheskie jevol'ventnye vneshnego zaceplenija. Raschet geometrii [State Standard 16532-70. Cilindrical involute external gear pairs. Calculation of geometry]. Moscow, Standarts Publ., 1983. 43 p. 5. ISO 21771:2007 Gears. Cylindrical involute gears and gear pairs. Concepts and geometry. 2007. 6. GOST 21354-87. Peredachi zubchatye cilindricheskie jevol'ventnye vneshnego zaceplenija. Raschet na prochnost' [State Standard 21354-87. Cylindrical evolvent gears of external engagment. Strength calculation]. Moscow, Standarts Publ., 1989. 76 p. 7. ISO 6336:2006 Metod B. Calculation of load capacity of spur and helical gears. 2006. 8. Ustinenko A.V. Matematicheskoe modelirovanie processov ustalostnogo razrushenija zub'ev [Mathematical modeling of processes of fatigue failure teeth]. Visnyk NTU "KhPI". Zbirnyk naukovykh prats'. Serija Mashynoznavstvo ta SAPR [Bulletin of the NTU "KhPI". The collection of scientific works. Series Engineering and CAD], 2012, no. 22, pp. 170-175. 9. Pavlyshe V. T. Osnovy konstrujuvannja ta rozrahunok detalej mashyn [Fundamentals of design and calculation of machine parts]. L'viv, Afisha Publ., 2003. 560 p. 10. ANSYS: Engineering Simulation Software. Available at: https://www.ansys.com/ (accessed 19 December 2021). 11. Inventor 
Nastran: CAD-embedded finite element analysis. Available at: https://www.autodesk.com/products/inventornastran/overview (accessed 19 December 2021).

\title{
Олександр Ковальчук, Роман Бережний, Володимир Нежебовський, Олександр Устиненко, Харків, Україна
}

\section{АНАЛІЗ НАПРУЖЕНОСТІ ТА ДОВГОВІЧНОСТІ ОСНОВНИХ ДЕТАЛЕЙ РІЖУЧОЇ ЧАСТИНИ ОЧИСНОГО КОМБАЙНУ УКД 200-500}

\begin{abstract}
Анотація. $A T$ "Харківський машинобудівний завод "Світло шахтаря" створив та впровадив у серійне виробниџтво очисний комбайн нового покоління УКД 200-500. Найбільш відповідальним та навантаженим елементом комбайна $\epsilon$ його ріжуча частина. Вона являє собою триступінчастий прямозубий редуктор з електродвигуном. Ріжуча частина є уніфікованою. Це дозволяє встановлювати ї̈ як з лівого, так $i$ з правого боку рами. Кожен ступінь редуктора розташований в окремій герметичній камері, захищеній від проникнення абразивних частинок. У процесі проектування було виконано великий обсяг розрахунків його основних деталей на міцність та довговічність: контактної та згинальної міцності та витривалості зубчастих зачеплень; валів на статичну та втомну міџність; терміну служби та статичної міџності підшипників; шліцьових, итифтових та шарнірних з'єднань; моделювання напруженодеформованого стану основних деталей та вузлів методом скінченних елементів. Розрахунки зубчастих передач, валів, підщипників илічьових, итифтових та шарнірних з'єднань виконувались за допомогою загальноприйнятих інженерних методик. Також для зубчастих передач уточнювали допустимі напруження на основі математичного моделювання втомних процесів у зубиях. Розрахунки показали, ще міџність та довговічність усіх зубчастих коліс та валів забезпечені; розрахунковий термін служби по динамічній вантажопідйомності усіх підшипників забезпечений, а запаси по статичної вантажопідйомності перевищують мінімально допустимі значення; розрахункові запаси міџності для шліџьових, итифтових та шарнірних з'єднань перевищують мінімально допустимі значення. Моделювання напруженодеформованого стану за допомогою метода скінченних елементів дозволило оцінити міцність деталей та вузлів складної конфігураиії, таких як корпус, водило планетарного ступеня та інших. Ці розрахунки показали, щз за рівнем максимальних напружень усі деталі задовольняють умовам міџності. Це дозволяє зробити висновок, щчо розроблена конструкція ріжучої частини комбайна забезпечує необхідну довговічність 15000 год та середній ресурс до капітального ремонту (залежно від опірності вугілля різанню) не менше $800 \ldots 1000$ тис. m.
\end{abstract}

Ключові слова: очисний комбайн; ріжуча частина; зубчаста передача; міцність; довговічність; напруження. 